\title{
A suggested statistical approach for dealing with the non-significant interactions between treatments
}

\author{
Zakaria Mohamed Sawan
}

Cotton Research Institute, Agricultural Research Center, Ministry of Agriculture and Land Reclamation, Giza, Egypt; zmsawan@hotmail.com

Received 21 January 2011; revised 20 February 2011; accepted 20 March 2011.

\begin{abstract}
A field experiment was conducted to study the effect of nitrogen $(\mathrm{N})$ fertilizer and foliar application of potassium (K) and Mepiquat Chloride (MC) on yield of cotton. Seed cotton yield per plant and seed cotton and lint yield per hectare; have been increased due to the higher $\mathrm{N}$ rate and use of foliar application of K and MC. No significant interactions were found among the variables in the present study (N,K and $M C$ ) with respect to characters under investigation. Generally, interactions indicated that, the favorable effects ascribed to the application of $\mathrm{N}$; spraying cotton plants with $\mathrm{K}$ combined with MC on cotton productivity, were more obvious by applying $N$ at $143 \mathrm{~kg}$ per hectare, and combined with spraying cotton plants with $\mathrm{K}$ at $957 \mathrm{~g}$ per hectare and also with MC at $48+24 \mathrm{~g}$ active ingredient per hectare. Sensible increases were found in seed cotton yield per hectare (about $40 \%$ ) as a result of applying the same combination. However, this interaction did not reach the level of significance, so, statistical approach for dealing with the non-significant interactions between treatments, depending on the Least Significant Difference values has been suggested, to provide an opportunity to disclosure of the interaction effects regardless of their insignificance. As a matter of fact the original formula used in calculating the significance of interactions suffers a possible shortage, which can be eliminated through applying the new suggested formula.
\end{abstract}

Keywords: Cotton Yield; Mepiquat Chloride; Nitrogen; Non-Significant Interactions; Potassium

\section{INTRODUCTION}

Managing the balance of vegetative and reproductive growth is the essence of managing a cotton crop. It is well known from numerous fertilizer experiments that the yield of field crop has been dependent strongly on the supply of mineral nutrients [1-3]. Excess of vegetative growth, poor bud development, shedding of fruiting forms, and growth imbalance between the source and sink are responsible for the unpredictable behavior of the crop. Several approaches have tried-out to break this yield plateau, among them the application of plant growth regulators (PGR's), particularly Mepiquat Chloride $(\mathrm{MC})$ that has received greater attention recent years $[4,5]$.

The objective of this study was to evaluate the effects of $\mathrm{N}$ fertilization rate, foliar $\mathrm{K}$ application, and $\mathrm{MC}$ application on the yield of cotton with the aim to identify production treatments that may improve the yield. Also, we suggested a statistical approach for dealing with the non-significant interactions between treatments depending on the Least Significant Difference values, regardless of statistical insignificance.

\section{MATERIALS AND METHODS}

A Field experiment was conducted at the Agricultural Research Center, Ministry of Agriculture in Giza $\left(30^{\circ} \mathrm{N}\right.$, $31^{\circ} 28^{\prime} \mathrm{E}$ and $19 \mathrm{~m}$ altitude), Egypt using the cotton cultivar "Giza 86" (Gossypium barbadense L.) in I and II seasons. The soil texture in both seasons was a clay loam, with an alluvial substratum, $(\mathrm{pH}=8.10,44.75 \%$ clay, $27.40 \%$ silt, $20.00 \%$ fine sand, $3.00 \%$ coarse sand, $2.85 \%$ calcium carbonate and $1.85 \%$ organic matter). Each experiment included 16 treatment combinations of: 1) two $\mathrm{N}$ rates (95 and $143 \mathrm{~kg} \mathrm{~N}$ per hectare), which were applied as ammonium nitrate $\left(\mathrm{NH}_{4} \mathrm{NO}_{3}, 33.5 \% \mathrm{~N}\right)$ at two equal doses, 6 and 8 weeks after planting. Each application (in the form of pinches beside each hill) was followed immediately by irrigation. 2$)$ four $\mathrm{K}$ rates $(0$, 319,638 and $957 \mathrm{~g} \mathrm{~K}$ per hectare) were applied as potassium sulfate $\left(\mathrm{K}_{2} \mathrm{SO}_{4}\right.$, " $40 \% \mathrm{~K}$ ") as a foliar spray, 70 and 95 days after planting (during square initiation and 
boll development stage). The solution volume applied was $960 \mathrm{~L}$ per hectare. 3) two rates from the PGR, 1,1-dimethylpiperidinium chloride (Mepiquat Chloride "MC" or "Pix") were foliar applied (75 days after planting at 0 or $48 \mathrm{~g}$ active ingredient per hectare, 90 days after planting at 0 and $24 \mathrm{~g}$ active ingredient per hectare) where the solution volume applied was also $960 \mathrm{~L}$ per hectare. The $\mathrm{K}$ and MC were applied to the leaves with uniform coverage using a knapsack sprayer. The pressure used was $0.4 \mathrm{~kg}$ per $\mathrm{cm}^{2}$, resulting in a nozzle output of $1.43 \mathrm{~L}$ per min. The application was carried out between 9.0 and $11.0 \mathrm{~h}$.

A randomized complete block design with four replications was used for both experiments. Seeds were planted on 3 April, in season I and 20 April, in season II. Plot size was $1.95 \times 4 \mathrm{~m}$ including three ridges (beds) (after the precaution of border effect was taken into consideration). Hills were spaced $25 \mathrm{~cm}$ apart on one side of the ridge, with seedlings thinned to two plants hill ${ }^{-1}$ six weeks after planting. This provided a plant density of 123000 plants per hectare. The total amount of irrigation applied during the growing season (surface irrigation) was about $6000-\mathrm{m}^{3}$ per hectare. The first irrigation was applied three weeks after planting, with the second three weeks later. Thereafter, plots were irrigated every two weeks until the end of the season (October 11, in season I and October 17, in season II, respectively), for a total of nine irrigations. On the basis of soil test results, phosphorus $(\mathrm{P})$ fertilizer was applied at the rate of $24 \mathrm{~kg}$ $\mathrm{P}$ per hectare as calcium super phosphate during land preparation. The $\mathrm{K}$ fertilizer was applied at the rate of $47 \mathrm{~kg} \mathrm{~K}$ per hectare as potassium sulfate before the first irrigation (the recommended level for semi-fertile soil). Fertilization (P and $\mathrm{K}$ ), along with pest and weed management was carried out during the growing season, according to the local practice performed at the experimental station.

In both seasons, ten plants were randomly taken from the center ridge of each plot to determine the seed cotton yield in $g$ per plant. First hand picking was made on 20 and 26 September and final picking on 11 and 17 October in season I, and season II, respectively. Total seed cotton yield of each plot (including ten plant sub samples) was ginned to determine seed cotton and lint yield (kg per hectare).

Results were analyzed as a factorial experiment in a randomized complete block design for the studied characters each season and the combined statistical analysis for the two seasons, following the procedure outlined by Snedecor and Cochran [6]. The Least Significant Difference (L.S.D.) test method, at 5\% level of significance was used to verify the significance of differences among treatment means and the interactions to determine the optimum combination of $\mathrm{N}, \mathrm{K}$ and $\mathrm{MC}$.

\section{RESULTS AND DISCUSSION}

Results from the analysis of variance for yield (combined data of the two seasons) are presented in Table 1.

\subsection{Effects of Main Treatments on Yield}

Seed cotton yield per plant, as well as seed cotton and lint yield per hectare, were increased by as much as 12.8 , 12.8 , and $12.3 \%$, respectively, when the nitrogen rate was increased (Table 2). There were both increased boll numbers and boll weight, which was attributed to the fact that $\mathrm{N}$ is an important nutrient for control of new growth and preventing abscission of squares and bolls and is also essential for photosynthetic activity $[7,8]$. When $\mathrm{K}$ was applied at all three $\mathrm{K}$ rates $(319,638$ and $957 \mathrm{~g} \mathrm{~K}$ per hectare), seed cotton yield plant ${ }^{-1}$ and seed cotton and lint yield $\mathrm{ha}^{-1}$ were also increased. These increases could be attributed to the favorable effects of $\mathrm{K}$ on yield components, i.e. number of opened bolls per plant, and boll weight, leading consequently to higher cotton yield $[9,10]$. Mepiquat Chloride, significantly increased seed cotton yield per plant, as well as seed cotton and lint yield per hectare (by $9.5,9.6$, and 9.3\%, respectively), compared to the untreated control. These results may be attributed to the promoting effect of this substance that has beneficial and supplemental affects leading to yield enhancement (boll retention and boll weight) [11].

\subsection{Effects of Interactions between Treatments on Yield}

No significant interactions were found among the variables in the present study ( $\mathrm{N}$ rates, $\mathrm{K}$ rates and $\mathrm{MC}$ ) with respect to the characters under investigation. Generally, interactions indicated that, the favorable effects accompanied the application of N; spraying cotton plants with $\mathrm{K}$ combined with $\mathrm{MC}$ on cotton productivity, was more obvious by applying $\mathrm{N}$ at $143 \mathrm{~kg}$ per hectare, and combined with spraying cotton plants with $\mathrm{K}$ at $957 \mathrm{~g}$ per hectare and also with $\mathrm{MC}$ at $48+24 \mathrm{~g}$ active ingredient per hectare. Regarding the non-significant interaction effects, sensible increases were found in seed cotton yield per hectare (about $40 \%$ ) as a result of applying the same combination.

In this experiment there are sensible differences between the interactions, i.e. the first order (Tables 3-5), and the second order (Table 6). However, these interactions did not reach the level of significance, so, suggested statistical approach for dealing with the non-significant interactions between treatments, depending on the Least Significant Difference values to verify the sig- 
Table 1. Mean squares for combined analysis of variance for yield in cotton during season I and season II.

\begin{tabular}{|c|c|c|c|c|}
\hline Source & d.f. & $\begin{array}{l}\text { Seed cotton yield } \\
\text { (g per plant) }\end{array}$ & $\begin{array}{l}\text { Seed cotton yield } \\
\text { (kg per hectare) }\end{array}$ & $\begin{array}{c}\text { Lint yield } \\
\text { (kg per hectare) }\end{array}$ \\
\hline Year & 1 & $147.21 * *$ & $1415571.4^{* *}$ & $332917.8^{* *}$ \\
\hline Replicates within years & 6 & $40.27 *$ & $404859.0^{*}$ & $50458.4^{*}$ \\
\hline$\underline{\text { Treatments }}$ & $\underline{15}$ & $\underline{75.94 * *}$ & $\underline{714189.8 * *}$ & $\underline{83868.9 * *}$ \\
\hline Nitrogen $(\mathrm{N})$ & 1 & $456.74 * *$ & $4325402.3^{* *}$ & $500162.5^{* *}$ \\
\hline Potassium (K) & 3 & $132.53 * *$ & $1223590.9^{* *}$ & $145491.8^{* *}$ \\
\hline Mepiquat Chloride (MC) & 1 & $261.15 * *$ & $2504937.5^{* *}$ & $294768.0^{* *}$ \\
\hline $\mathrm{N} \times \mathrm{K}$ & 3 & 3.47 & 31778.5 & 3934.8 \\
\hline $\mathrm{N} \times \mathrm{MC}$ & 1 & 0.17 & 1463.4 & 298.6 \\
\hline $\mathrm{K} \times \mathrm{MC}$ & 3 & 4.19 & 36432.4 & 4632.6 \\
\hline $\mathrm{N} \times \mathrm{K} \times \mathrm{MC}$ & 3 & 0.18 & 1879.3 & 209.1 \\
\hline Treatments $\times$ Year & 15 & 2.50 & 24239.8 & 3070.9 \\
\hline Error & 90 & 14.36 & 135377.4 & 16752.8 \\
\hline \multicolumn{2}{|c|}{ SD } & 3.79 & 367.9 & 129.4 \\
\hline \multicolumn{2}{|c|}{ CV\% } & 12.04 & 12.0 & 12.0 \\
\hline
\end{tabular}

*Significant at $\mathrm{P}=0.05 ; * *$ Significant at $\mathrm{P}=0.01$.

Table 2. Effect of N-rate and foliar application of $\mathrm{K}$ and $\mathrm{MC}$ on yield in cotton combined over two seasons I and II.

\begin{tabular}{|c|c|c|c|}
\hline Treatment & Seed cotton yield (g per plant) & Seed cotton yield (kg per hectare) & Lint yield (kg per hectare) \\
\hline \multicolumn{4}{|c|}{$\mathrm{N}$ rate (kg per hectare) } \\
\hline 95 & $29.58^{\mathrm{b}}$ & $2882.3^{\mathrm{b}}$ & $1020.0^{\mathrm{b}}$ \\
\hline 143 & $33.36^{\mathrm{a}}$ & $3250.0^{\mathrm{a}}$ & $1145.0^{\mathrm{a}}$ \\
\hline $\operatorname{LSD}(0.05)$ & 1.33 & 128.9 & 45.4 \\
\hline \multicolumn{4}{|c|}{$\mathrm{K}$ rate (g per hectare) } \\
\hline 0 & $28.61^{\mathrm{b}}$ & $2792.5^{\mathrm{b}}$ & $988.2^{\mathrm{b}}$ \\
\hline 319 & $31.51^{\mathrm{a}}$ & $3068.6^{\mathrm{a}}$ & $1083.4^{\mathrm{a}}$ \\
\hline 638 & $32.51^{\mathrm{a}}$ & $3163.0^{\mathrm{a}}$ & $1115.2^{\mathrm{a}}$ \\
\hline 957 & $33.25^{\mathrm{a}}$ & $3240.7^{\mathrm{a}}$ & $1143.1^{\mathrm{a}}$ \\
\hline $\operatorname{LSD}(0.05)$ & 1.88 & 182.3 & 64.1 \\
\hline \multicolumn{4}{|c|}{$\mathrm{MC}$ rate (g per hectare) } \\
\hline 0 & $30.04^{\mathrm{b}}$ & $2926.3^{\mathrm{b}}$ & $1034.5^{\mathrm{b}}$ \\
\hline $48+24$ & $32.90^{\mathrm{a}}$ & $3206.1^{\mathrm{a}}$ & $1130.5^{\mathrm{a}}$ \\
\hline $\operatorname{LSD}(0.05)$ & 1.33 & 128.9 & 45.4 \\
\hline SD & 3.79 & 367.9 & 129.4 \\
\hline $\mathrm{CV} \%$ & 12.04 & 12.0 & 12.0 \\
\hline
\end{tabular}

Values followed by the same letter in a column are not significantly different from each other at $\mathrm{P}=0.05$. 
Table 3. Effect of interaction between $\mathrm{N}$ rate and foliar application of $\mathrm{K}$ on yield combined over two seasons I and II.

\begin{tabular}{|c|c|c|c|c|c|c|}
\hline \multirow{3}{*}{$\begin{array}{c}\text { K rate } \\
\text { (g per hectare) }\end{array}$} & \multicolumn{2}{|c|}{ Seed cotton yield (g per plant) } & \multicolumn{2}{|c|}{ Seed cotton yield (kg per hectare) } & \multicolumn{2}{|c|}{ Lint yield (kg per hectare) } \\
\hline & \multicolumn{6}{|c|}{$\mathrm{N}$ rate (kg per hectare) } \\
\hline & 95 & 143 & 95 & 143 & 95 & 143 \\
\hline 0 & $27.04^{\mathrm{d}}$ & $30.18^{\mathrm{c}}$ & $2639.2^{\mathrm{d}}$ & $2945.8^{\mathrm{c}}$ & $936.0^{\mathrm{d}}$ & $1040.3^{\mathrm{c}}$ \\
\hline 319 & $29.73^{\mathrm{c}}$ & $33.28^{\mathrm{ab}}$ & $2896.6^{\mathrm{c}}$ & $3240.5^{\mathrm{ab}}$ & $1025.3^{\mathrm{c}}$ & $1141.5^{\mathrm{ab}}$ \\
\hline 638 & $30.16^{\mathrm{c}}$ & $34.86^{\mathrm{a}}$ & $2935.5^{\mathrm{c}}$ & $3390.4^{\mathrm{a}}$ & $1037.2^{\mathrm{c}}$ & $1193.3^{\mathrm{a}}$ \\
\hline 957 & $31.38^{\mathrm{bc}}$ & $35.11^{\mathrm{a}}$ & $3058.0^{\mathrm{bc}}$ & $3423.3^{\mathrm{a}}$ & $1081.4^{\mathrm{bc}}$ & $1204.7^{\mathrm{a}}$ \\
\hline $\operatorname{LSD}(0.05)^{\dagger}$ & \multicolumn{2}{|c|}{2.66} & \multicolumn{2}{|c|}{257.8} & \multicolumn{2}{|c|}{90.7} \\
\hline
\end{tabular}

Values followed by the same letter in columns under every character head are not significantly different from each other at $\mathrm{P}=0.05$; ${ }^{\dagger} \mathrm{LSD}, \mathrm{Least}$ significant difference.

Table 4. Effect of interaction between $\mathrm{N}$ rate and foliar application of MC on yield combined over two seasons I and II.

\begin{tabular}{|c|c|c|c|c|c|c|}
\hline Character & Seed cott & per plant) & Seed cotton & per hectare) & Lint yie & hectare) \\
\hline \multirow{2}{*}{$\begin{array}{c}\mathrm{N} \text { rate } \\
\text { (kg per hectare) }\end{array}$} & \multicolumn{6}{|c|}{$\mathrm{MC}$ rate (g per hectare) } \\
\hline & 0 & $48+24$ & 0 & $48+24$ & 0 & $48+24$ \\
\hline 95 & $28.11^{\mathrm{c}}$ & $31.04^{\mathrm{b}}$ & $2739.1^{\mathrm{c}}$ & $3025.6^{\mathrm{b}}$ & $970.4^{\mathrm{c}}$ & $1069.5^{\mathrm{b}}$ \\
\hline 143 & $31.96^{\mathrm{b}}$ & $34.75^{\mathrm{a}}$ & $3113.5^{\mathrm{b}}$ & $3386.5^{\mathrm{a}}$ & $1098.5^{\mathrm{b}}$ & $1191.4^{\mathrm{a}}$ \\
\hline $\operatorname{LSD}(0.05)^{\dagger}$ & \multicolumn{2}{|c|}{1.88} & \multicolumn{2}{|c|}{182.3} & \multicolumn{2}{|c|}{64.1} \\
\hline
\end{tabular}

Values followed by the same letter in columns under every character head are not significantly different from each other at $\mathrm{P}=0.05$; ${ }^{\dagger} \mathrm{LSD}$, Least significant difference.

Table 5. Effect of interaction between $\mathrm{K}$ rate and foliar application of MC on yield combined over two seasons I and II.

\begin{tabular}{|c|c|c|c|c|c|c|}
\hline \multirow{3}{*}{$\begin{array}{c}\text { K rate } \\
\text { (g per hectare) }\end{array}$} & \multicolumn{2}{|c|}{ Seed cotton yield (g per plant) } & \multicolumn{2}{|c|}{ Seed cotton yield (kg per hectare) } & \multicolumn{2}{|c|}{ Lint yield ( $\mathrm{kg}$ per hectare) } \\
\hline & \multicolumn{6}{|c|}{$\mathrm{MC}$ rate (g per hectare) } \\
\hline & 0 & $48+24$ & 0 & $48+24$ & 0 & $48+24$ \\
\hline 0 & $27.22^{\mathrm{c}}$ & $29.99^{b}$ & $2655.0^{\mathrm{c}}$ & $2930.0^{\mathrm{b}}$ & $941.1^{\mathrm{c}}$ & $1035.3^{\mathrm{b}}$ \\
\hline 319 & $29.66^{\mathrm{bc}}$ & $33.35^{\mathrm{a}}$ & $2891.3^{\mathrm{bc}}$ & $3245.8^{\mathrm{a}}$ & $1022.0^{\mathrm{bc}}$ & $1144.9^{\mathrm{a}}$ \\
\hline 638 & $31.00^{\mathrm{b}}$ & $34.03^{\mathrm{a}}$ & $3014.1^{\mathrm{b}}$ & $3311.8^{\mathrm{a}}$ & $1064.2^{\mathrm{b}}$ & $1166.3^{\mathrm{a}}$ \\
\hline 957 & $32.28^{\mathrm{ab}}$ & $34.21^{\mathrm{a}}$ & $3144.7^{\mathrm{ab}}$ & $3336.6^{\mathrm{a}}$ & $1110.7^{\mathrm{ab}}$ & $1175.5^{\mathrm{a}}$ \\
\hline $\operatorname{LSD}(0.05)^{\dagger}$ & \multicolumn{2}{|c|}{2.66} & \multicolumn{2}{|c|}{257.8} & \multicolumn{2}{|c|}{90.7} \\
\hline
\end{tabular}

Values followed by the same letter in columns under every character head are not significantly different from each other at $\mathrm{P}=0.05 ;{ }^{\dagger} \mathrm{LSD}, \mathrm{Le}$. nificant difference.

nificant between treatment combinations regardless of the non-significance of the interaction effects from the ANOVA, to reach a balance between experience and level of statistics as shown in Tables 3-6. It is quite possible that the experimental error could mask the pronounced effects of the interactions.

In this manner, we found from the results that, if there were no significant differences existed between the different levels of any main factor (N, K or MC), in such case if the Least Significant Difference was calculated, the significance would not be existed. On the other hand, if the significance of the interactions between the main factors (first \& second order interactions) did not existed, the estimation of Least Significant Difference of the interactions between the main factors, could give significant result.

Thus, it could be said that the formula used in calculating the significance of interactions suffers a possible shortage.

We think that, it could be useful to modify or add 
Table 6. Effect of interactions between $\mathrm{N}$ rate, foliar application of $\mathrm{K}$ and $\mathrm{MC}$ on yield in cotton combined over two seasons I and II.

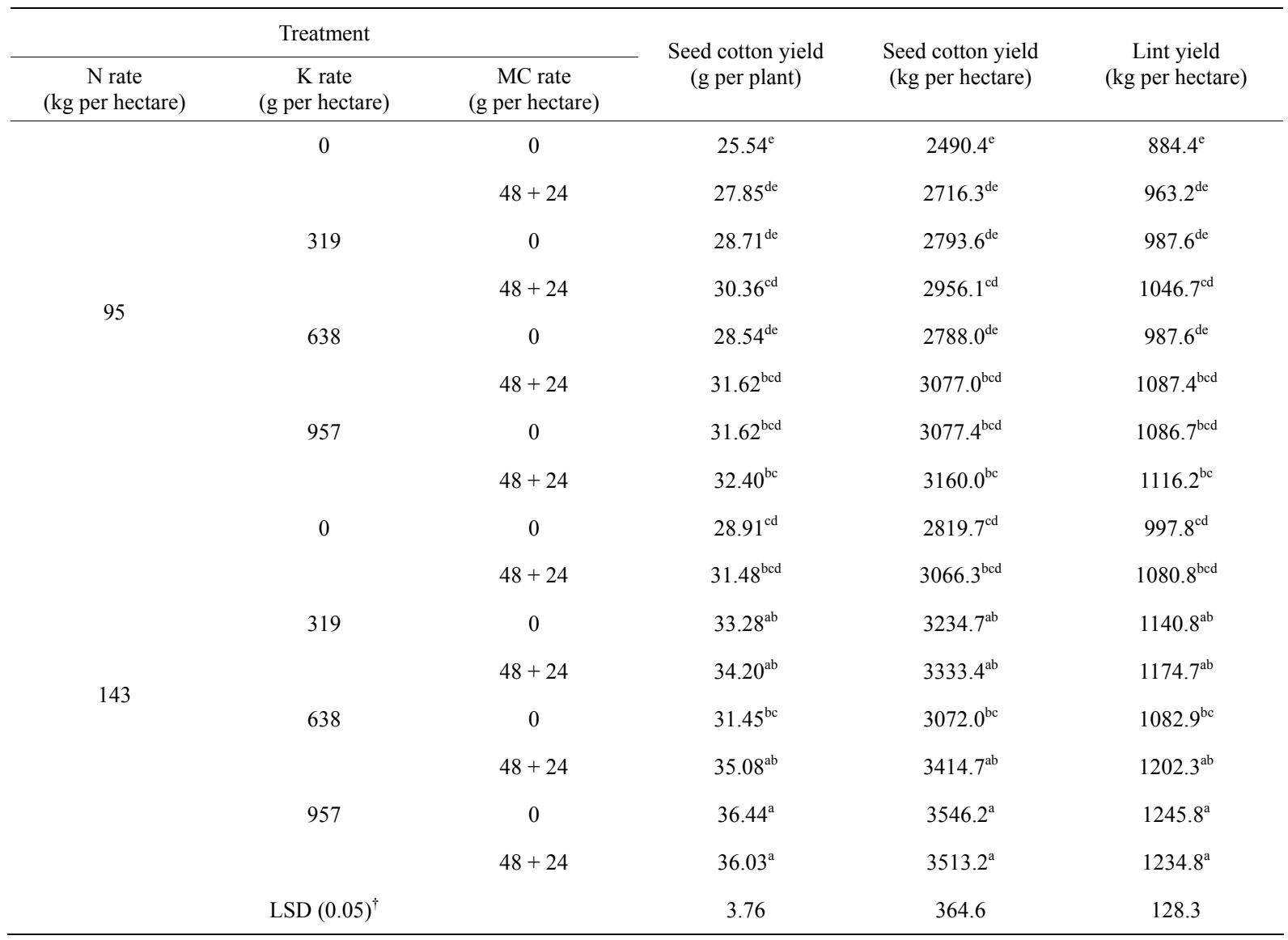

Means followed by the same letter in a column are not significantly different from each other at $P=0.05$; ${ }^{\dagger}$ LSD, Least significant difference.

some additions to the original formula used for calculating $F$ values of interactions:

$F=$ Mean square for interaction / Mean square for error

In this connection, we could suggest that when calculating the significance of interactions we could calculate it as follow:

$\mathrm{F}=$ Mean square for interaction $\times \mathrm{n} /$ Root of mean square for error (suggested formula)

where $\mathrm{n}=$ number of main factors in the interaction.

We strongly believe that the use of the suggested formula, would secure the disclosure of the significant effects of the interactions regardless of the high experimental error.

\section{REFERENCES}

[1] Gormus, O. (2002) Effects of rate and time of potassium application on cotton yield and quality in Turkey. Journal of Agronomy and Crop Science, 188, 382-388. doi:10.1046/j.1439-037X.2002.00583.x

[2] Ansari, M.S. and Mahey, R.K. (2003) Growth and yield of cotton species as affected by sowing dates and nitrogen levels. Journal of Research, Punjab Agricultural University, 40, 8-11.

[3] Pervez, H., Ashraf, M. and Makhdum, M.I. (2004) Influence of potassium rates and sources on seed cotton yield and yield components of some elite cotton cultivars. Journal of Plant Nutrition, 27, 1295-1317. doi:10.1081/PLN-120038549

[4] Nuti, R.C., Witten, T.K., Jost, P.H. and Cothren, J.T. (2000) Comparisons of pix plus and additional foliar Bacillus cereus in cotton. Proceedings Beltwide Cotton Production Research Conference, San Antonio, 4-8 January 2000, 684-687.

[5] Kumar, K.A.K., Patil, B.C. and Chetti, M.B. (2004) Effect of plant growth regulators on biophysical, biochemical parameters and yield of hybrid cotton. Karnataka Journal of Agricultural Science, 16, 591-594.

[6] Snedecor, G.W. and Cochran, W.G. (1980) Statistical Methods. 7th Edition, Iowa State University Press, Ames.

[7] McConnell, J.S. and Mozaffari, M. (2004) Yield, petiole nitrate, and node development responses of cotton to early season nitrogen fertilization. Journal of Plant $\mathrm{Nu}$ trition, 27, 1183-1197. doi:10.1081/PLN-120038543

[8] Wiatrak, P.J., Wright, D.L. and Marois, J.J. (2006) Development and yields of cotton under two tillage systems 
and nitrogen application following white lupine grain crop. Journal Cotton Science, 10, 1-8.

[9] Pettigrew, W.T., Meredith, W.R. Jr. and Young, L.D. (2005) Potassium fertilization effects on cotton lint yield, yield components, and reniform nematode populations. Agronomy Journal, 97, 1245-1251. doi:10.2134/agronj2004.0321

[10] Sharma, S.K. and Sundar, S. (2007) Yield, yield attributes and quality of cotton as influenced by foliar application of potassium. Journal of Cotton Research and Development, 21, 51-54.

[11] Prakash, R., Prasad, M. and Pachauri, D.K. (2001) Effect of nitrogen, chlormequat chloride and FYM on growth yield and quality of cotton (Gossypium hirsutum L.). Annals of Agricultural Research, 22, 107-110. 